\title{
Modulation of paraoxonases during infectious diseases and its potential impact on atherosclerosis
}

\author{
Ayman Samir Farid ${ }^{1,2}$ and Yoichiro Horii ${ }^{*}$
}

\begin{abstract}
The paraoxonase (PON) gene family includes three members, PON1, PON2 and PON3, aligned in tandem on chromosome 7 in humans and on chromosome 6 in mice. All PON proteins share considerable structural homology and have the capacity to protect cells from oxidative stress; therefore, they have been implicated in the pathogenesis of several inflammatory diseases, particularly atherosclerosis. The major goal of this review is to highlight the modulation of each of the PONs by infective (bacterial, viral and parasitic) agents, which may shed a light on the interaction between infectious diseases and PONs activities in order to effectively reduce the risk of developing atherosclerosis.
\end{abstract}

Keywords: Atherosclerosis, Paraoxonases, Oxidative stress, Infectious diseases

\section{Introduction}

The desire to understand the correlation between infection, inflammation and oxidative stress in various diseases, including atherosclerosis, has captured the imagination of many investigators. The involved mechanisms are strictly regulated and possibly interconnected in order to maintain oxidative homeostasis in cells and tissues. Understanding the biology and function of such mechanisms will pave the way for discovery of novel therapeutic agents in the fight against various inflammatory diseases.

The paraoxonases (PONs) comprise a family of closely related enzymes that includes PON1, PON2 and PON3, and these are aligned next to one another on chromosome 7 in humans and on chromosome 6 in mice. PONs share around $70 \%$ nucleic acid identities and are believed to be derived from a common precursor $[1,2]$.

In this review, we focused on the effects of infectious agents on PONs, emphasizing its potential roles against infections and elucidating the relationship between infection and atherosclerosis.

\footnotetext{
* Correspondence: horii@cc.miyazaki-.ac.jp

${ }^{2}$ Laboratory of Parasitic Diseases, Faculty of Agriculture, University of

Miyazaki, Gakuen-Kibanadai, Nishi 1-1, Miyazaki 889-2192, Japan

Full list of author information is available at the end of the article
}

\section{Physiological roles of PONs}

PONs have different cell and tissue distributions, as well as different regulatory mechanisms, thus suggesting distinct physiological roles for each of them. These roles, however, remain largely unknown [3] especially in the light of the crucial fact that the physiological substrates of PONs remain still poorly known. Indeed, the most striking characteristic of PONs is their multitasking capacity, which allows PONs to play a role in several different pathways, not only limited to lipid oxidation metabolism but also including the intriguing field of innate immunity.

\section{PON1}

PON1 is the most studied member of the PON family and much of our understanding of the PON enzymes is derived primarily from studies involving PON1 protein. In humans, the PON1 gene is mainly expressed in the liver, giving a protein product of 354 amino acids with a molecular mass of $43-45 \mathrm{kDa}$, and is released into normal circulation [4]. There is growing evidence from experimental, clinical and epidemiological studies that underscores the role of PON1 in protection against atherosclerosis [5]; however, the precise mechanisms remain elusive. 
The enzymatic activity for which the enzyme is named is screened by using synthetic substrates without regard for the native substrate or its role in human (patho)biology [6]. The ability of PON1 to hydrolyze paraoxon was employed as a method to measure PON1 activity in several species and tissues. PON1 paraoxonase enzymatic activity can be modulated by polymorphisms in the PON1 gene locus, including the Q192R polymorphism, in which glutamine $(\mathrm{Q})$ is replaced by arginine $(\mathrm{R})$ at position 192. The $\mathrm{Q}$ isoform has low activity in hydrolyzing paraoxon, while the $\mathrm{R}$ isoform shows high activity [4]. PON1 also possesses arylesterase activity, with phenyl acetate being one of its best substrates. Furthermore, PON1 exhibits good lactonase activity; hydrolyzing a wide range of lactones [7].

Although PON1's natural substrates are uncertain, thioester homocysteine (Hcy)-thiolactone, which is a product of an error editing reaction in protein biosynthesis formed when Hcy is mistakenly selected by methionyl-tRNA synthetase, is hydrolyzed to Hcy by PON1 $[3,4]$. Therefore, it has been suggested that PON1 should be properly named homocysteine-thiolactonase [8]. Hcy is a risk factor for the development of cardiovascular disease [9]. Proposed mechanisms underlying Hcy pathobiology include protein modification by Hcythiolactone, oxidative stress, inflammation, autoimmune response, endothelial dysfunction, and thrombosis [10]. Thus, the Hcy-thiolactonase activity of PON1 is likely to contribute to the cardioprotective role of PON1.

Most serum PON1 is associated with the cholesterolcarrying high-density lipoprotein (HDL) ("good cholesterol") through its retained N-terminal hydrophobic region. HDL is important for PON1 secretion and stabilization by HDL-associated apolipoprotein A-I; however, less than $5 \%$ of serum PON1 is also associated with chylomicrons and VLDL, but not LDL [11]. Several lines of evidence have suggested that PON1 protects against atherosclerosis by its evident ability to guard low-density lipoproteins (LDL) against oxidative stress, reduce macrophage foam cell formation, and prevent atherosclerosis development (Figure 1). In the artery wall, PON1 inhibits LDL oxidation, in doing so prevents the ox-LDL-induced up-regulation of monocyte chemoattractant protein-1 (MCP-1) production by endothelial cells [12,13]. MCP-1 displays chemotactic activity for monocytes into the intima that differentiate into macrophages. The latter take up ox-LDL in an unregulated manner to become foam cells [14], which leads to atherosclerotic plaque development $[15,16]$. Since the control of cholesterol efflux is of vital relevance for foam cell formation, PON1 also enhances cholesterol efflux from macrophages [17] and inhibits macrophage cholesterol biosynthesis [18]. Such roles suggest that PON1 has crucial effects on the initial steps of atherosclerosis.
The special localization of PON1 in the HDL complex of human serum led to speculation that the enzyme plays also an important physiological role in lipid metabolism and that it protects against the development of atherosclerosis [19]. This notion was confirmed by the capacity of PON1 to hydrolyze lipid peroxides, which prevents foam cell formation [20]. More interestingly, a recent study by Deakin et al. [21] showed that PON1 is not a fixed component of HDL can exert its protective function outside the lipoprotein environment since it can be transferred from HDLs to the external face of the plasma membrane of cells in an enzymatically active form conferring protection against oxidative stress.

Another important clue regarding the physiological function of PON1 has been provided by studies in mice lacking this enzyme. Shih et al. [22] found that PON1 "knockout" (KO) mice develop atherosclerosis when fed an atherogenic diet, and their HDL, in contrast to wildtype HDL, failed to prevent LDL oxidation in cultured artery wall cells. This study clearly established the antioxidative and anti-inflammatory potential of PON1 in vivo and also showed its potential role in the prevention of atherosclerosis. Moreover, mice with combined PON1/apoE KO exhibited more atherosclerosis than apoE KO mice and their LDL particles were more susceptible to oxidation [23]. Furthermore, PON1-deficient mice showed increased oxidative stress in macrophages, which could be related to the activation of cellular nicotinamide adenine dinucleotide phosphate (NADPH) oxidase and to a decrease in cellular reduced glutathione (GSH) content. On the other hand, purified PON1 directly reduced macrophage oxidative stress [18].

Owing to the development of genetically modified PON1 KO and transgenic ( $\mathrm{Tg}$ ) mice, the potential roles of PON1 in the context of macrophage functions could be studied. HDL from human PON1 Tg mice increased cholesterol efflux from mouse peritoneal macrophages (MPM) and the J774 A.1 macrophage cell line via the ATP-binding cassette (ABCA1) transporter, and the binding activity to the same macrophage cell types also increased. In addition, the presence of high PON1 levels in HDL induced the formation of lysophosphatidylcholine (LPC) in the macrophages, which is thought to increase HDL binding to macrophages and thus contributes to a more important cholesterol efflux via an apoA-I-mediated mechanism. These results indicate that PON1 status on HDL particles will influence binding to macrophages and cholesterol efflux, further demonstrating the beneficial effects of PON1 in the early stages of atherosclerosis $[17,24]$.

Recently, the absence of PON1 in mice was associated with a broad array of vascular changes, including enhanced oxidative stress and thrombogenicity, as well as significant increases in leukocyte adhesion and mRNA 


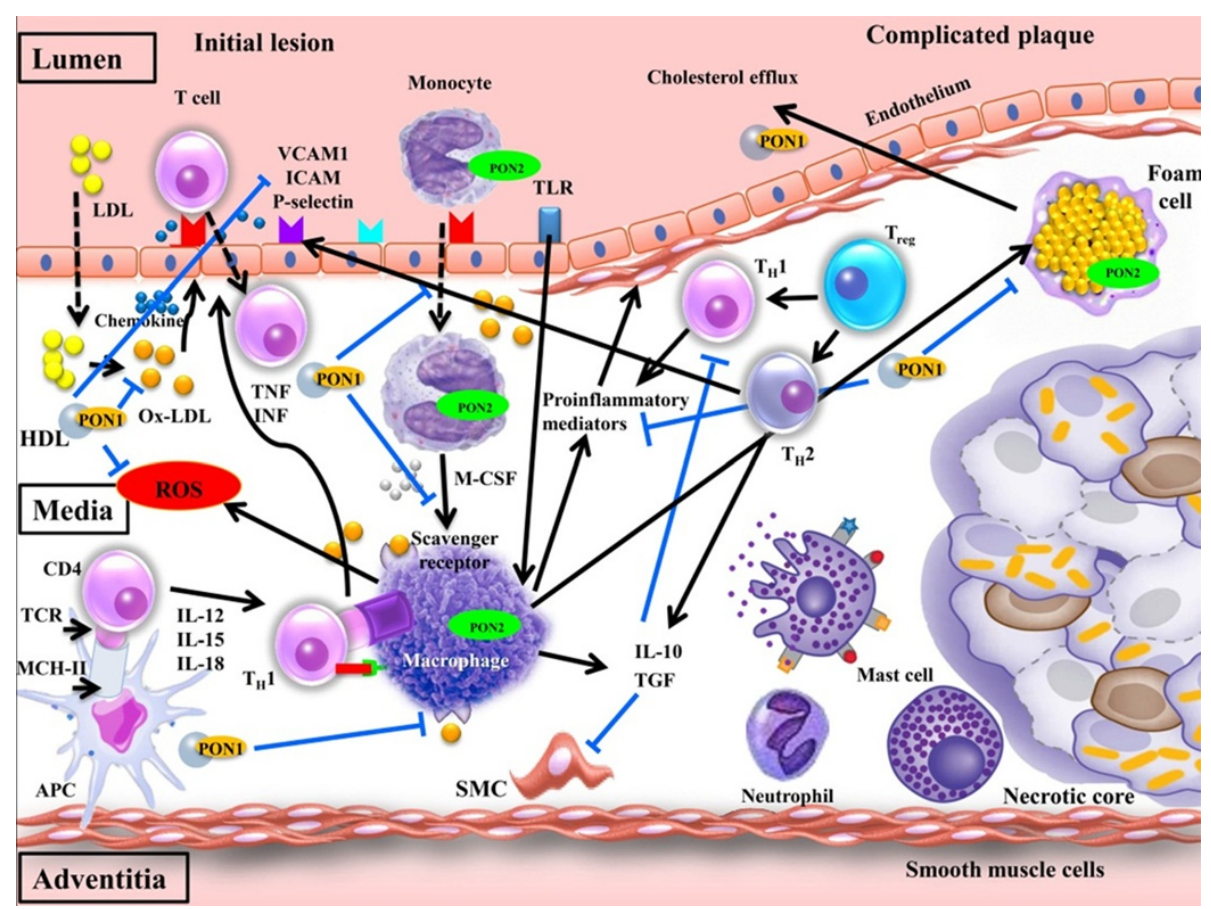

Figure $1 \mathrm{~A}$ proposed mechanism for atherosclerosis development and the roles of PON1 and PON2 against atherosclerosis. Moving from left to right, low-density lipoprotein ( $L D L)$ diffuses from the blood into the innermost layer of the artery. The LDL in the artery wall is modified by oxygen radicals to oxidized LDL (oxLDL) which in turn induces endothelial cells to express leukocyte adhesion molecules, such as vascular cell-adhesion molecule-1 (VCAM1), intercellular adhesion molecule-1 (ICAM-1), and P-selectins. Monocytes and T cells bind to adhesion molecules-expressing endothelial cells and respond to locally produced chemokines by migrating into the arterial tissue. Monocytes differentiate into macrophages in response to local macrophage colony-stimulating factor (M-CSF) and other stimuli. Scavenger receptors mediate macrophage uptake of ox-LDL particles, which leads to intracellular cholesterol accumulation and the formation of foam cells. Ox-LDL and other ligands promote the production of many pro-inflammatory molecules by macrophages. T cells undergo activation after interacting with antigenpresenting cells (APCs), such as macrophages or dendritic cells. A T helper $1\left(T_{H} 1\right)$-cell-dominated response ensues, possibly owing to the local production of interleukin-12 (IL-12), IL-18 and other cytokines. $T_{H} 1$ cells produce inflammatory cytokines including interferon-a (IFN-a) and tumour-necrosis factor (TNF). These cytokines and others prompt macrophage activation, production of other pro-inflammatory mediators, activate endothelial cells, increase adhesion-molecule expression and the propensity for thrombus formation, and stimulate proliferation and migration of smooth-muscle-cell as well as collagen production. Plaque inflammation might be attenuated in response to the anti-inflammatory cytokines IL-10 and transforming growth factor-a (TGF-a), which are produced by several cell types including regulatory $T$ and $T_{H} 2 c e l l s$, macrophages, and for TGF-a, also vascular cells and platelets. The atherosclerotic lesion has a core of lipids, including cholesterol crystals, living and apoptotic cells and a fibrous cap with smooth muscle cells and collagen. Several types of cells of the immune response are present throughout the atheroma including macrophages, T cells, mast cells and DCs. HDL-associated PON1 inhibits the influx of cholesterol by oxidized LDL into macrophages by reducing Ox-LDL levels, reducing Ox-LDL uptake via the macrophage scavenger receptor, reducing macrophage-mediated oxidation of LDL, and increasing the hydrolysis of macrophage oxidized lipids. HDL-associated PON1 also inhibits macrophage cholesterol biosynthesis and enhances HDL-mediated cholesterol efflux. Monocyte/macrophage-associated PON2 also protects LDL against oxidation and reduces the oxidative stress caused by preformed ox-LDL. TCR; T-cell receptor, TLR; Toll-like receptor, MCH; Major histocompatibility complex, ROS; Reactive oxygen species.

levels of the aortic adhesion molecule $\mathrm{P}$ selectin and inter-cellular adhesion molecule-1 (ICAM1). Aortic superoxide production was also significantly higher in PON1 KO animals when compared with wild-type controls [25].

PON1 may confer protection against macrophage apoptosis under basal conditions via LPC formation and further by up-regulation of the macrophage scavenger receptor class $\mathrm{B}$, type I (SR-BI)-mediated HDL binding to the cells. As macrophage apoptosis is an important feature of atherosclerotic plaque development, PON1 deficiency may lead to the enhanced atherosclerosis development observed in mice, as a result of reduced SR-BI-mediated HDL protection against apoptosis [26].

More recently, HDL-associated PON1 inhibits monocyte-to-macrophage differentiation. Monocytederived macrophages play a central role in the development of arterial foam cells and atherosclerotic lesions. Such action could lead to attenuation of macrophage foam cell formation and atherosclerosis development [27]. Therefore, PON1 is closely linked to the control of oxidative stress and inflammation, mainly at the circulation level, where its association with HDL particles is related to the prevention of atherosclerosis $[25,28]$. 


\section{PON2}

Human PON2 is ubiquitously expressed and is found in various tissues with primary localization in the plasma membrane, which suggests that its functions are distinct from those reported for PON1 and PON3 [29]. While little is known about the physiological or pathophysiological role of this protein, PON2 has been reported to possess anti-oxidant properties. In addition to its ability to reduce the oxidative stress caused by preformed mildly oxidized LDL, decreasing LDL-mediated induction of inflammatory response in cells [29], PON2 can also protect LDL against oxidation [30]. Thus, one function of PON2 may be to act as a cellular anti-oxidant, protecting cells from oxidative stress.

Animal studies have shown that mice subjected to adenovirus-mediated expression of PON2 (AdPON2) have an increased anti-oxidant capacity with lower levels of lipid hydroperoxides when compared to mice treated with either PBS or empty vector. Although PON2 is not normally found in circulation and was not detected in the serum of these mice, its effect may be induced by modulating the properties of circulating lipoproteins, for example, affecting the susceptibility of LDL to oxidation and the capacity of HDL to protect LDL against oxidation [31].

On the other hand, when subjected to a high-fat diet for 15 weeks, PON2-deficient animals developed significantly larger (2.7-fold) atherosclerotic lesions when compared with controls. Moreover, LDL isolated from these animals was more susceptible to oxidation and induced a greater degree of monocyte chemotaxis. Furthermore, there was enhanced macrophage trafficking into the artery wall in PON2-deficient mice, as determined by macrophage staining in aortic sections using CD68 as a marker. When macrophages were isolated from PON2deficient mice, they exhibited both higher levels of oxidative stress and enhanced pro-inflammatory properties, as well as showing increased tumor necrosis factor (TNF)- $\alpha$ and interleukin (IL)- $1 \beta$ gene expression after LPS-induced inflammation [32].

PON2 may exert significant protection against macrophage triglyceride (TG) accumulation, macrophage TG biosynthesis, microsomal diacylglycerol acyltransferase 1 (DGAT1) activity and macrophage oxidative stress, in the presence and absence of glucose [33,34] (Figure 1). PON2 gene and protein expression have been detected in various parts of the human gastrointestinal tract [35], and the addition of purified PON2 to permeabilized intestinal Caco-2 cells protects against iron-ascorbateinduced oxidative stress [36]. Surprisingly, PON2 protein was detected on the apical (luminal) side of Caco- 2 culture medium, raising the possibility that the intestinal cells are capable of secreting PON2 into the intestinal lumen, where it may perform another, as yet unclear function [35], possibly against infectious agents.

\section{PON3}

PON3 was the last of the paraoxonases to be characterized. Draganov et al. [37] were the first to purify and characterize rabbit plasma PON3. Several studies then demonstrated that PON3 protects against oxidation and inflammation, thus suggesting that PON3 is atheroprotective $[5,38,39]$. Draganov and his colleagues reported that rabbit PON3 purified from serum was capable of inhibiting copper-induced LDL oxidation in vitro to a greater degree than rabbit PON1 [37]. Reddy et al. [40] showed that pretreatment with cultured human aortic endothelial cells with supernatants from HeLa Tet On cell lines overexpressing PON3 prevents the formation of mildly oxidized LDL and inactivates preformed mildly oxidized LDL. Rosenblat et al. [30] demonstrated the presence of PON3 in murine macrophages, but not human macrophages, which suggests that mouse PON3 influences atherogenesis more directly through its expression in artery wall cells.

AdPON3 in 26-week-old apolipoprotein E-deficient mice was also shown to protect against atherosclerosis, with mice showing significantly lower levels of serum lipid hydroperoxides and enhanced potential for cholesterol efflux from cholesterol-loaded macrophages. In addition, LDL was less susceptible to oxidation, whereas HDL was more capable of protecting against LDL oxidation. These results confirmed that although human PON3 in mice did not reside in HDL particles, the reduction in atheroma is mediated by the ability of PON3 to enhance the anti-atherogenic properties of plasma [41].

A study by Shih et al. [42] demonstrated that overexpression of human PON3 decreases atherosclerotic lesion formation in transgenic mice (C57Bl6/J and LDLRKO background; $55 \%$ and 34\% reduction, respectively), in a male-specific fashion. In addition, male PON3 Tg mice maintained on either low-fat chow or high-fat Western diet exhibited decreased adiposity when compared with age and diet-matched, male nonTg littermates. Moreover, this study showed that elevated human PON3 expression decreased obesity in male mice. These findings suggest a protective role for PON3 against atherosclerosis and obesity.

One of the interesting physiological functions of all three PONs is the ability, via lactonase activity, to hydrolyze and inactivate bacterial quorum sensing (QS). QS molecules are extracellular signals secreted by Gram-negative bacteria to regulate biofilm formation and secretion of virulence factors $[43,44]$. Of the three PONs, PON2 appears to have the highest activity against the QS factors. The second member to have evolved is proposed to be PON3, followed by PON1 [7]. This function of PONs indicates their potential importance as novel components of innate immunity. 
These findings clearly demonstrate the important protective roles played by PONs against inflammation and oxidative stress. It is possible that PON2 fulfills these crucial functions in various organs, whereas HDLassociated PON1 and PON3 primarily act in blood circulation.

\section{Mutual relationship between PONs and infections}

Numerous risk factors are involved in the development of atherosclerosis, such as hypertension, cigarette smoking, diabetes, hyperlipidemia and hypercoagulability [45]. However, as many as $50 \%$ of patients with atherosclerosis lack the abovementioned risk factors, which suggests that there are additional factors predisposing individuals to atherosclerosis $[46,47]$.

There are multiple epidemiological studies to support the notion that infections can be considered risk factors for atherosclerosis. The paradigm that infection by bacteria and/or viruses is a risk factor for atherosclerosis via direct infection of vascular cells or via the indirect effects of cytokines or acute-phase proteins induced by infection at non-vascular sites [48] emphasizes the "infectious hypothesis" of atherosclerosis. This relates to current atherogenesis theories that accept the crucial role of inflammation in the development of atherosclerotic plaques [49]; however, the role of some kind of infections (like parasitic infection) on atherosclerosis and related anti-atherogenic mechanisms (including PONs) remains uncertain.

\section{PONs and bacterial infections}

Experimental studies have indicated that PON1 activity is altered during the acute-phase response. LPS injection, which mimics Gram-negative infections, in mice increases serum amyloid A (SAA) through nuclear factor $-\kappa \mathrm{B}(\mathrm{NF}-\kappa \mathrm{B})$ transactivation and decreases apoA-I and PON1 by inhibiting peroxisome proliferatoractivated receptor (PPAR)- $\alpha$ activation. TNF- $\alpha$, IL- $1 \beta$ and IL- 6 mediate these changes through stimulation of hepatocytes [50]. Bin Ali et al. [51] also found that LPS induces a further $50 \%$ decrease in hepatic PON1 mRNA in male mice and moderate increases in female mice through pro-inflammatory cytokine (IL- $1 \beta$ and TNF- $\alpha$ )unmediated pathways. However, these pro-inflammatory cytokines have been shown to up-regulate (IL-6) or down-regulate (IL- $1 \beta$ and TNF- $\alpha$ ) PON1 gene expression in HepG2 human hepatoma cells [52].

Similarly to previous results, mice with $18 \mathrm{G}$ cecal ligation and puncture (CLP) to induce slow leakage of intestinal flora in the abdominal cavity exhibit gradual onset sepsis that closely mimics human sepsis. Plasma paraoxonase activity decreases up to 24 hours post-CLP in association with increased IL-6 and decreased HDL levels, and PON1 activity is positively correlated with total anti-oxidant activity. The cause-effect relationship between decreased PON1 activity and increased oxidative stress has not been established, but it is most likely a dynamic bi-directional relationship [53].

Human clinical studies have shown that in septic patients there are significant decreases in plasma PON1 (paraoxonase and arylesterase) activity, and this is negatively correlated with C-reactive protein (CRP), which is produced in response to the oxidizing environment induced by sepsis. This increased binding of free radicals to PON1 accounts for the decrease in PON1 activity in the circulation [54].

More recently, Naderi et al. [55] showed that patients with pulmonary tuberculosis have significantly lower paraoxonase and arylesterase activities when compared with healthy subjects. This reduction is most likely due to imbalance of oxidant/anti-oxidant systems in pulmonary tuberculosis patients, as supported by the findings of Nezami et al. [56], who found decreased levels of total anti-oxidant capacity, red blood cell superoxide dismutase activity and whole blood glutathione peroxidase activity with increased levels of malondialdehyde in pulmonary tuberculosis cases, thus suggesting a higher susceptibility of LDL to oxidation and higher levels of lipid peroxidation. This environment clearly provides a higher risk for atherosclerosis.

At the same time, epidemiological studies in humans indicated that infection by Helicobacter pylori, a potential cause of atherosclerosis, significantly decreases serum paraoxonase and arylesterase activities. This decrease may be attributed to decreases in HDL-C and, in part, to increased oxidative stress and inflammatory conditions induced by $H$. pylori infection [57].

Chlamydia pneumoniae is an obligate intracellular bacterium that causes acute and chronic respiratory disease in humans and is associated with an increased risk of cardiovascular disease $[58,59]$. Infection of mice with C. pneumoniae reduces serum PON1 activity and the anti-inflammatory properties of HDL by repressing gene expression via serum amyloid A elevation [50]. In addition, acute infection is associated with an increase in the frequency of intra-plaque hemorrhage [60]. These results indicate that $C$. pneumoniae contributes to the progression and destabilization of atherosclerotic lesions.

Interestingly, the expression of human PON1 in transgenic Drosophila results in increased resistance to infection by Pseudomonas aeruginosa via inactivation of the QS factor $N$-(3-oxododecanoyl)-L-homoserine lactone (3OC12-HSL) of Pseudomonas [61]. In vitro studies using PON1 KO mouse serum have shown that PON1 is important for degradation of 3OC12-HSL [61] through its lactonase activity [7,62]; thus, playing an important role in the fight against bacterial biofilm formation [63]. Importantly, chronic $P$. aeruginosa infection in the lung 
can stimulate atherogenesis in the aorta and coronary artery under a cholesterol-supplemented diet [64]. As PON1 has the ability to inactivate QS in Gram-negative bacteria, it is possible that under physiological conditions, PON1 (mostly with PON2 and PON3) can prevent the bacterial colonization associated with several proinflammatory factors, including QS molecules and atherogenic lipids [65]. These results indicate that PON1, in addition to its anti-atherogenic role, can also be considered part of the innate immune system [66].

While little is known about its role, PON2 appears to have the highest activity against QS factors. As the pulmonary system is a primary site of infection for $P$. aeruginosa, experiments using airway epithelial cells cultured from PON2-KO mice and a QS reporter strain of $P$. aeruginosa confirmed a two-fold increase in QS. This indicates that deficiency of PON2 impairs 3OC12-HSL degradation by airway epithelial cells and that diffusion of 3OC12-HSL into airway cells is the rate-limiting step for degradation of the molecule, irrespective of bacterial density [67]. Thus, PON2 expression does not appear to affect the growth of $P$. aeruginosa, but degrades the bacterial QS signal.

Knockdown of PON2 by transfecting cells with smallinterfering RNA (siRNA) in human aortic endothelial cells treated with 3OC12-HSL or oxidized 1-palmitoyl-2 -arachidonoyl-sn-glycero-3-phosphocholine (Ox-PAPC) resulted in increased pro-inflammatory response (IL-8, COX 2 , IL- $1 \beta$ and ICAM-1), apoptosis markers and unfolded protein response (UPR) [68]. This indicates that anti-atherogenic effects of PON2 include destruction of QS molecules.

The $P$. aeruginosa QS signal 3OC12, which is inactivated by PON2 [67], has the ability to down-regulate PON2 mRNA, protein and hydrolytic activity in A549 and EA.hy 926 cell cultures. These decreases were at least partly mediated by increases in cytosolic $\mathrm{Ca}^{2+}$, which mediates the degradation of PON2 protein and mRNA [69]. The hydrolytic activity of PON2 was decreased much more extensively and rapidly than the protein, indicating a likely post-translational event that blocks the hydrolytic activity of PON2. These findings not only support a role for PON2 in the defense against $P$. aeruginosa virulence, but also reveal a potential mechanism by which the bacterium may subvert the protection afforded by PON2 [70].

The third member of the PON family, PON3, is expressed in the skin, salivary gland, glandular epithelium of the stomach, intestine, liver hepatocytes, pancreatic acinar cells, heart, adipose tissue and bronchiolar epithelium, with differences in distribution patterns between humans and mice $[35,39,71]$. To date, there has been relatively little learned about PON3. However, in addition to its anti-atherogenic and anti-obesity effects
$[41,42]$, PON3 is known to hydrolyze bacterial QS molecules, such as 3OC12-HSL $[7,63]$; therefore, it is plausible that the presence of PON3 plays a protective role against bacterial infection.

\section{PONs and viral infections}

Several epidemiological studies have assessed the association between viral infection and the development of atherosclerosis (Table 1). In the late 1970s, experimental infection of germ-free chickens with an avian herpesvirus induced an arterial disease that resembled human atherosclerosis [72].

Experimental study has shown that intranasal inoculation of influenza A strain WSN/33 in C57BL/6 J mice results in significant decreases in the activities of paraoxonase and the platelet-activating factor acetylhydrolase, which reached their lowest levels by day 7 after infection. This was associated with lower HDL antiinflammatory properties and increased monocyte/ macrophage trafficking into arteries. If this is the case in human infection, these changes might explain the increased risk for heart attack and stroke after influenza infection [76].

Hepatitis $\mathrm{C}$ virus ( $\mathrm{HCV}$ ) is a major cause of viral hepatitis. There are approximately 170 million people worldwide who are chronically infected by this virus. Infection by $\mathrm{HCV}$ does not typically resolve, and nearly $80 \%$ of infected individuals become chronic carriers who may then progress to severe liver diseases [97]. HCV infection is associated with increased oxidative stress, which is marked by an increase in oxidants and a decrease in anti-oxidant capacity of the cells [97]. In addition to the contribution by chronic inflammation caused by infection, direct induction of reactive oxygen species/reactive nitrogen species (ROS/RNS) and mitochondrial dysfunction by the virus is likely.

In cell culture systems, HCV expression, replication and infection can induce oxidative stress [98-100]. Subsequently, oxidative stress has been identified as a significant mechanistic pathway culminating in the development of hepatic damage [101]. As PON1 exerts a protective effect against oxidative stress, it is plausible that there is an association between this enzyme and liver impairment. A study by Ali et al. [77] confirmed that there were significant decreases in PON1 (paraoxonase and arylesterase) activity in chronic and cirrhotic HCV patients with higher serum nitric oxide levels and myeloperoxidase activity. These results are consistent with those of Ferré et al. [102], who studied rats with carbon tetrachloride-induced fibrosis and showed decreased PON1 activity and an inverse correlation with lipid peroxidation, while the addition of zinc as an antioxidant was associated with enhanced PON1 activity and normalization of lipid peroxidation. These results 
Table 1 Potential infectious causes of atherosclerosis and/or underlying diseases

\begin{tabular}{|c|c|c|c|c|c|c|}
\hline Infection & Host & Affected PONs & Effect on PONs & Mediator(s) & $\begin{array}{l}\text { Atherosclerotic } \\
\text { effect/heart attack }\end{array}$ & References \\
\hline \multicolumn{7}{|c|}{ Bacterial infections } \\
\hline \multirow[t]{6}{*}{ LPS } & Human & PON1 & $\downarrow$ & $\begin{array}{l}\text { Oxidative stress and oxidative } \\
\text { modification of } \mathrm{HDL}\end{array}$ & + & {$[53,54]$} \\
\hline & Mice (male) & PON1 & $\downarrow$ & $\begin{array}{l}\text { - Decrease hepatic PON1 synthesis } \\
\text { - Oxidative stress }\end{array}$ & + & $\begin{array}{l}\bullet[51,73] \\
\bullet[53]\end{array}$ \\
\hline & (female) & PON1 & $\uparrow \downarrow$ & $\begin{array}{l}\text { - Increased hepatic PON1 synthesis } \\
\text { (in case of } \uparrow \text { ) } \\
\text { - Oxidative stress (in case of } \downarrow \text { ) }\end{array}$ & + & $\begin{array}{l}\bullet[51] \\
\bullet[53,74]\end{array}$ \\
\hline & Syrian hamster & PON1 & $\downarrow$ & $\begin{array}{l}\text { (TNF- } a \text { and IL-1)-mediated } \\
\text { down-regulated hepatic } \\
\text { PON1 mRNA }\end{array}$ & & {$[75]$} \\
\hline & HepG2 human hepatoma cells & PON1 & $\downarrow$ & $\begin{array}{l}(\mathrm{IL}-1 \beta \text { and TNF- } \alpha) \text {-mediated } \\
\text { hepatic PON1 down-regulation }\end{array}$ & & {$[52]$} \\
\hline & HepG2 human hepatoma cells & PON1 & $\uparrow$ & $\begin{array}{l}\text { (IL-6)-mediated hepatic PON1 } \\
\text { up-regulation }\end{array}$ & & {$[52]$} \\
\hline Pulmonary tuberculosis & Human & PON1 & $\downarrow$ & $\begin{array}{l}\text { Oxidant/anti-oxidant } \\
\text { systems imbalance }\end{array}$ & + & [55] \\
\hline Helicobacter pylori & Human & PON1 & $\downarrow$ & $\begin{array}{l}\text { Oxidative stress and } \\
\text { oxidative modification of HDL }\end{array}$ & + & {$[57]$} \\
\hline Chlamydia pneumoniae & Mice & PON1 & $\downarrow$ & $\begin{array}{l}\text { Down-regulate hepatic } \\
\text { PON1 mRNA }\end{array}$ & + & {$[50]$} \\
\hline Pseudomonas aeruginosa & $\begin{array}{l}\text { A549 and EA.hy } 926 \\
\text { cell cultures }\end{array}$ & PON2 & $\downarrow$ & Down-regulate PON2 mRNA & & [69] \\
\hline \multicolumn{7}{|c|}{ Viral infections } \\
\hline Influenza A strain WSN/33 & C57BL/6 J mice & PON1 & $\downarrow$ & $\begin{array}{l}\text { Decreased hepatic PON1 } \\
\text { protein synthesis }\end{array}$ & + & {$[76]$} \\
\hline Hepatitis C virus (HCV) & Human & PON1 & $\downarrow$ & $\begin{array}{l}\text { Oxidant/anti-oxidant } \\
\text { systems imbalance }\end{array}$ & + & [77] \\
\hline HCV & Human & PON3 & $\uparrow$ & $\begin{array}{l}\text { Oxidant/anti-oxidant } \\
\text { systems imbalance }\end{array}$ & + & {$[78]$} \\
\hline Hepatitis B virus (HBV) & Human & PON1 & $\downarrow$ & $\begin{array}{l}\text { - Oxidant/anti-oxidant systems imbalance } \\
\text { - Decrease (dysfunction) of HDL } \\
\text { - Decrease (dysfunction) of ApoA-1 }\end{array}$ & & $\begin{array}{l}\bullet[79] \\
\bullet[80] \\
\bullet[81,82]\end{array}$ \\
\hline Human immunodeficiency virus (HIV) & Human & PON1 & $\downarrow$ & $\begin{array}{l}\text { Decrease (dysfunction) } \\
\text { of } \mathrm{HDL}\end{array}$ & + & {$[83,84]$} \\
\hline HIV & $\begin{array}{l}\mathrm{CD}^{+} 4^{+} \mathrm{CD} 4^{+} \text {hematopoietic } \\
\text { cell line TF-1 and thymocytes } \\
\text { derived from the human } \\
\text { fetal conjoint thymus/liver } \\
\text { hematopoietic organ of } \\
\text { SCID-hu mice }\end{array}$ & PON2 & $\uparrow$ & $\begin{array}{l}\text { Up-regulation of cellular } \\
\text { PON2 mRNA expression }\end{array}$ & & {$[85]$} \\
\hline
\end{tabular}


Table 1 Potential infectious causes of atherosclerosis and/or underlying diseases (Continued)

\begin{tabular}{|c|c|c|c|c|c|c|}
\hline HIV & Human & PON3 & $\uparrow$ & Oxidative stress & + & [86] \\
\hline \multicolumn{7}{|c|}{ Parasitic infections } \\
\hline Trypanosoma cruzi (Chagas' disease) & Human & $\begin{array}{l}\text { PON1 } \\
\text { PON2 } \\
\text { PON3 }\end{array}$ & \pm & $\begin{array}{l}\text { - Oxidative stress, } \\
\text { apoA-I miss structure } \\
\text { - } \mathrm{T}_{\mathrm{H}} 1 \text { immune polarization }\end{array}$ & \pm & $\begin{array}{l}\bullet \\
\bullet\end{array}[87]$ \\
\hline Nippostrongylus brasiliensis & Rat & PON1 & $\downarrow$ & $\begin{array}{l}\text { Pro-inflammatory } \\
\text { cytokines-mediated } \\
\text { hepatic PON1 } \\
\text { down-regulation }\end{array}$ & \pm & [92-94] \\
\hline Trichinella spiralis & Rat & PON1 & $\downarrow$ & $\begin{array}{l}\text { Oxidant/anti-oxidant } \\
\text { systems imbalance }\end{array}$ & \pm & [95] \\
\hline Schistosoma mansoni & Mice & $\begin{array}{l}\text { Hepatic } \\
\text { PON1 }\end{array}$ & $\downarrow$ & Oxidative stress & - & [96] \\
\hline
\end{tabular}

The arrows $\uparrow$ and $\downarrow$ represent increased and decreased PONs activity.

The symbols,+- and \pm mean, respectively, increase, decrease and unknown effect on atherosclerosis. 
suggest that PON1 activity is involved in the defense against free radical production in liver organelles.

Although PON1 enzyme activity is a more important factor in atherosclerosis and coronary heart disease than PON1 genotype [103,104], it is interesting to observe that there was a higher frequency of the RR isoform of the 192 polymorphism in healthy subjects than in those with chronic HCV infection [105]. This is supported by the results of Aviram et al. [106], who found that the PON1Q allele appears to be more efficient than the PON1R allele in hydrolyzing lipid peroxides in both coronary and carotid lesion homogenates. Mackness et al. [103] also showed that the $\mathrm{R}$ allele is associated with a modest increase in the risk of coronary heart disease.

On the other hand, serum PON3 concentration, in patients with chronic hepatic impairment as a consequence of $\mathrm{HCV}$ infection, is significantly elevated when compared with control subjects, and its concentration is related to the severity of the periportal alterations and to serological markers of anti-apoptosis, thus suggesting an anti-apoptotic role for PON3 [78].

Another type of hepatitis caused by viral infection, hepatitis B, also showed lower serum paraoxonase and arylesterase activities in chronic active hepatitis B patients when compared with inactive carriers and control individuals [80]. This observation is supported by the results of Schulpis et al. [79], who found decreased paraoxonase and arylesterase activities in mothers with HBV disease, mostly due to the liver damage and low total anti-oxidant capacity. This reduction of serum PON1 activity during HBV infection may be the result of changes in synthesis or secretion of HDL [107], and significant decreases [81] and post-transcriptional modification of nascent ApoA-1 [82]. It is likely that PON1 protects HDL from oxidation and this is likely to be related to the attributed HDL-antiapoptotic function [79]; therefore, PON1 may contribute to the protective effects of HDL in maintaining lower levels of HBV DNA [108].

Several prospective and retrospective studies have established the association between human immunodeficiency virus (HIV) infection and atherosclerotic coronary artery disease [109]. Inflammation has been recognized as the key pathologic process leading to early atherosclerosis. Patients with HIV have an enhanced state of inflammation. Several specific pathways of inflammation linking HIV infection to increased cardiovascular risk have been elucidated. HIV-infected individuals have higher CRP values and higher circulating concentrations of the adhesion molecules intercellular adhesion molecule-1 (ICAM-1) and vascular cell adhesion molecule-1 (VCAM-1), as compared with uninfected individuals $[110,111]$.

There are several key changes in lipoprotein metabolism in the course of HIV infection, including increased lipid peroxidation, hypocholesterolemia and hypertriglyceridemia, and decreased HDL concentration [83]. This explains the significant decrease in serum PON1 activity in HIV-infected patients [84]. Anti-retroviral therapy using non-nucleoside reverse transcriptase inhibitors such as nevirapine increases HDL concentration and apoA-I production. Concomitantly, modest increases in lecithin:cholesterol acyltransferase and cholesteryl ester transfer protein activity are also observed [112]. It is likely that apoA-I increases the stability and activity of PON1 [113] in treated patients, which may contribute to the beneficial effects of high HDL concentration in HIVinfected patients.

Changes in PON1 activity play a role in the course of HIV infection, which is an area that is worthy of further investigation. PON1 may also play an anti-infective role, as this enzyme increases cholesterol efflux from the cell, as well as the binding of the HDL particle to its receptor (ABCA1) [17]. Membrane metabolism is modulated by the efflux of cholesterol to the HDL particle, and this phenomenon would influence HIV replication, as the virus requires cholesterol rafts in the plasma membrane for final assembly and entry into the cell. In addition, there is a positive association between serum PON1 activity and CD4+ T lymphocyte count and its serum concentration with $\beta$-2-microglobulin; the latter being an effective marker of HIV infection activity [84].

In contrast to PON1 activity during HIV infection, both in vitro and in vivo studies have shown increased PON2 activity and up-regulation of cellular PON2 mRNA expression upon HIV-1 infection in the CD34 ${ }^{+} \mathrm{CD}_{4}{ }^{+}$hematopoietic cell line TF- 1 and in thymocytes derived from the human fetal conjoint thymus/liver hematopoietic organ of SCID-hu mice. HIV-1 infection results in dephosphorylation of STAT5 in the absence of granulocyte-macrophage colony stimulating factor (GM-CSF), and this is associated with increases in PON2 gene expression, activity and protein levels, thus indicating that PON2 is part of the innate immune response to viral infections [85].

On the other hand, PON3 concentrations also increase significantly (about three times) in HIV-infected patients with respect to controls and are inversely correlated with oxidized LDL levels, which indicates that PON3 plays a protective role against oxidative stress and increased lipid peroxidation in HIV infection [86]. Long-term use of non-nucleoside reverse transcriptase inhibitor (NNRTI)-based anti-retroviral therapy is associated with a decrease of PON3 concentrations. NNRTI promotes anti-atherogenic changes in HDL form and function, including normalization of size and lipid composition and enhancement of reverse cholesterol transport, and induces higher PON1 activity [114,115]. These effects, together with the increased concentration before 
treatment, indicate that PON3 is not associated with the presence of sub-clinical atherosclerosis in HIV-infected patients, although lipid peroxidation and atherosclerosis are known to be strongly linked to such infection [116]. Therefore, PON3 is in some way involved in protection against HIV infection [86].

\section{PONs and parasitic infections}

In the battle against parasitic infection, host immune response is central, but this also carries a cost. For example, generation of oxidative stress is an important factor in immune activation [117]. The generation of oxidants during parasitic infection occurs via three routes: first, they are released by immune cells that use their cytotoxic effects to kill the pathogen; second, oxidants are by-products of oxygen consumption, and increased metabolic activity during an immune response may contribute to the generation of additional toxic oxidants; and third, parasites themselves can be directly responsible for oxidant release through degradation products of their own metabolism. While useful in immune protection, non-targeting toxic oxidants have a potentially important negative side-effect by damaging host tissues and obstructing their function [118].

Considering the "oxidative modification hypothesis" of atherogenesis [16,119], together with the chronicity of several types of parasitic infection that can influence the host for years to decades [120,121], discussing the effects of parasitic infections and their associated immune responses on PON activity in the context of atherosclerosis remains of clinical importance.

The protozoan parasite Trypanosoma cruzi causes Chagas' disease, which is a major endemic problem from the southern United States to temperate South America [122]. Infection invokes alteration in the microvascular and macrovascular circulation and severe cardiomyopathy [123]. Although epidemiological studies in humans did not show a direct linkage between Chagas' disease and atherosclerosis [124], experimental studies, using in vivo and in vitro models, demonstrated cellular infiltration $\left(\mathrm{CD}^{+}\right.$and $\left.\mathrm{CD}^{+}\right)$and associated cytokine (IL-4, IL-5, IL-6 and TNF- $\alpha$ ) production in the heart $[88,89]$. Further studies showed increased expression of ICAM-1, IL- 6 and TNF- $\alpha$ in aortic endothelial cells with associated inflammation in the adventitia consisting mainly of $\mathrm{CD}^{+}$and $\mathrm{CD}^{+} \mathrm{T}$ cells and macrophages [125]. A recent study indicated that immune response polarization to a $\mathrm{T}_{\mathrm{H}} 1$ response during experimental $T$. cruzi infection is responsible for the development of the chronic cardiac form of the disease [90,91].

On the other hand, T. cruzi infection was found to induce oxidative stress in the host indicated by increased levels of TBARS and SOD [87]. Interestingly, HDL meets some of the nutritional needs of $T$. cruzi, as supported by the observation that epimastigote growth is slowed significantly in vitro by lipid depletion and that transition of $T$. cruzi trypomastigotes to amastigotes is accompanied by a shift from carbohydrate to lipiddependent energy metabolism [126,127]. Furthermore, exposure of cruzipain to human HDL during in vitro and in vivo infection in mice with $T$. cruzi generates several truncated apoA-I fragments [126]. Importantly, apoA-I, which is the major structural and functional protein component of HDL and is necessary for stabilizing and maintaining the optimum PON1 activity $[113,128]$, was mostly truncated in $T$. cruzi in the sera of human patients when compared with controls [126]. Raper et al. [129] demonstrated the presence of apoA-I and PON1 in both trypanosome lytic factors (TLF1 and TLF2) in human serum. In humans, these factors confer resistance to infection with cattle $T$. brucei brucei. The authors suggested that the presence of apoA-I, regardless of its concentration, is important in the assembly of lytic particles, as supported by the finding that serum from an individual with familial apoA-I deficiency is not trypanolytic [130]. Further studies confirmed that PON1 influences survival in mice infected with $T$. congolense; mice overexpressing PON1 had significantly longer lifespans than wild-type mice, and mice deficient in PON1 had significantly shorter lifespans [131].

The possible mechanisms by which PON1 may influence trypanosome virulence may be related to the role of PON1 in the immune response. PON1 has been shown to have anti-inflammatory properties $[13,132]$. This is supported by the observed trypanosome survival of a relatively short period of time (less than 10 days) after infection, thus indicating that it may be function of innate, rather than adaptive, immunity [131]. PON1 also has multiple enzymatic activities, including esterase and lactonase, which may be important against trypanosome infection.

The effects of the second most common parasitic infections caused by nematodes on PON1 activity were studies by Farid et al. [92,93] who showed that infection by Nippostrongylus brasiliensis, a gastrointestinal nematode that infects mice and rats and has a similar life cycle as human pathogens Ancylostoma duodenale and Necator americanus [133], reduces serum PON1 activity in male rats. Studies by the same group showed that $N$. brasiliensis infection in rats fed a high-fat diet led to reduced serum PON1 activity in association with an atherogenic lipid profile [94].

At least two possible mechanisms can be postulated for the observed decrease in PON1 activity during $N$. brasiliensis infection. The infected rats had downregulated hepatic PON1 expression, which is closely correlated with serum PON1 activity [4,75,134]. The mechanism by which hepatic PON1 mRNA is downregulated during $N$. brasiliensis infection in rats is 
induction by various pro-inflammatory cytokines associated with that infection. This notion is supported by the up-regulation of hepatic IL- $1 \beta$, IL- $1 \beta$ receptor ( $R$ ), TNF- $\alpha$ and TNFR1 mRNA expression. These results are consistent with the observation of increased serum levels of pro-inflammatory cytokines (IL-1, IL- 6 and TNF- $\alpha$ ) on day 9 after infection with $N$. brasiliensis [92], which provides evidence that hepatic PON1 mRNA is downregulated during $N$. brasiliensis infection in response to inflammatory conditions either in hepatic tissue or induced during larval migration. The role of proinflammatory cytokines in down-regulation of PON1 mRNA is primarily mediated by NF- $\kappa \mathrm{B}[50,52]$.

An alternative or complementary explanation is the increased levels of oxidative stress parameters (TBARS) [94] as a result of host immune-dependent damage to helminth parasites via a nonspecific defense reaction by the host [135]. These results in enhanced free radical production and oxidatively damaged macromolecules, and PON1 enzyme can be inactivated by these compounds [136]. This is supported by the results recently obtained by Mido et al. [95].

Another interesting finding was reported by Chelur et al. [137], who confirmed expression of PONs in the nematode Caenorhabditis elegans system. The expressed PONs are thought to interact with lipids, and this interaction may be crucial to the localization of the degenerin channel complexes to the specialized membrane domains mediating mechanotransduction in touch cells of the nematode.

The opposite appears to be the case for the third parasitic category of trematodes. The results obtained by Doenhoff et al. [138] showed that atherogenesis is reduced by approximately $50 \%$ when compared with uninfected controls in $\mathrm{apoE}^{-} /^{-}$mice subjected to low-intensity, chronic experimental infection with Schistosoma mansoni. The authors attributed this to parasitemediated effects on lipid metabolism. As schistosomes do not synthesize cholesterol [139] and the parasite breaks down LDL [140] via inducible LDL receptors, this would account for the decrease in blood cholesterol levels in infected animals. Alternatively, schistosome infection may reduce circulating lipid levels by inhibiting lecithin:cholesterol acyltransferase (LCAT) activity [141]. The mechanism by which schistosomiasis reduces atherosclerotic lesion development appears to be independent of the development of a $\mathrm{T}_{\mathrm{H}} 2$ environment, as exposure to eggs induces a classic $\mathrm{T}_{\mathrm{H}} 2$ response (IL-4, IL-5 and IL-13 production) but does not alter lesion progression [142,143].

The involvement of $\mathrm{T}_{\mathrm{H}} 2$ cells in atherosclerosis is ambiguous, but the notion is supported by the work of Stanley et al. [144], who found that the lipid-lowering effects of parasite eggs may be induced as a consequence of a granulomatous reaction against tissue-embedded eggs, rather than a direct response to the eggs themselves. These results are supported by a study by Helmy et al. [96], who showed that serum and liver arylesterase and paraoxonase activities were significantly lower in mice at 10 weeks after infection with $S$. mansoni, as compared to uninfected healthy mice. However, these activities are partially restored in infected animals receiving zinc as an anti-oxidant, indicating that the changes in PON1 are influenced by oxidative stress associated with infection.

As there are no more detailed studies on the relationship between parasitic infection and PONs, particularly PON2 and PON3, further mechanistic investigations would be valuable in exploring the measures to counteract the inflammatory and oxidative processes in parasitic infections and in providing new insights into the roles played by these infections during atherogenesis regarding that the typical immune response in the initial steps of atherogenesis is $\mathrm{T}_{\mathrm{H}} 1$ [145-147]. Switching the immune response from $T_{H} 1$ to $T_{H} 2$, which occurs in some parasitic infections, may induce secretion of the antiinflammatory cytokines, leading to slower progression of atherosclerotic lesion development $[146,148]$.

\section{Conclusion}

There is now growing evidence that PONs acting alone or in concert with other mechanistic pathways prevent/ retard atherosclerosis development in vivo. Under conditions such as infection, the anti-inflammatory and anti-atherogenic properties of PONs are reduced by proinflammatory proteins and/or associated oxidative stress. Therefore, detailed biochemical, cell-based, animal and epidemiological studies are necessary to further identify the physiological roles of PONs and the molecular mechanisms by which PONs render their protective effects against atherosclerosis. Future studies on the potential implications of PONs activity modulation (e.g. by means of recombinant human PON engineered for specific molecular target) during infectious disease are of great importance. In addition, it is of particular interest to speculate on a broader host defense role for PONs against bacterial, viral and parasitic infections.

\section{Abbreviations}

PON(1,2,3): paraoxonase-1,2,3; HDL: high-density lipoprotein; VLDL: very lowdensity lipoprotein; LDL: low-density lipoprotein; KO: "knockout";

NADPH: nicotinamide adenine dinucleotide phosphate; GSH: glutathione;

Tg: transgenic; MPM: mouse peritoneal macrophages; ABCA1: ATP-binding cassette; LPC: lysophosphatidylcholine; ICAM1: inter-cellular adhesion molecule-1; SR-BI: scavenger receptor class B, type I; TNF: tumor necrosis factor; IL-: interleukin -; LPS: lipopolysaccharide; DGAT1: diacylglycerol acyltransferase 1; QS: quorum sensing; NF-KB: nuclear factor-KB; PPAR: peroxisome proliferator-activated receptor; 3OC12-HSL: N-(3oxododecanoyl)-L-homoserine lactone; Ox-PAPC: oxidized 1-palmitoyl-2 -arachidonoyl-sn-glycero-3-phosphocholine; COX2: cyclooxygenase-2; UPR: unfolded protein response; ROS/RNS: reactive oxygen species/reactive 
nitrogen species; TBARS: thiobarbituric acid reactive substance;

SOD: superoxide dismutase.

\section{Competing interests}

The authors declare that they have no competing interests.

\section{Authors' contributions}

ASF and $\mathrm{YH}$ conceived and designed the manuscript. ASF wrote the manuscript, $\mathrm{YH}$ reviewed the manuscript. All authors approved the final version of the manuscript.

\section{Acknowledgements}

This work was supported in part by the Project for Zoonosis Education and Research, University of Miyazaki, Japan.

\section{Author details}

${ }^{1}$ Department of Clinical Pathology, Faculty of Veterinary Medicine, Benha University, Moshtohor, Toukh 13736, Qalyubia, Egypt. '2Laboratory of Parasitic Diseases, Faculty of Agriculture, University of Miyazaki, Gakuen-Kibanadai, Nishi 1-1, Miyazaki 889-2192, Japan.

Received: 9 May 2012 Accepted: 03 July 2012

Published: 23 July 2012

\section{References}

1. Sorenson RC, Primo-Parmo SL, Camper SA, La Du BN: The genetic mapping and gene structure of mouse paraoxonase/arylesterase. Genomics 1995, 30:431-438.

2. Primo-Parmo SL, Sorenson RC, Teiber J, La Du BN: The human serum paraoxonase/arylesterase gene (PON1) is one member of a multigene family. Genomics 1996, 33:498-507.

3. Draganov DI: Human PON3, effects beyond the HDL: clues from human PON3 transgenic mice. Circ Res 2007, 100:1104-1105.

4. Mackness MI, Mackness B, Durrington PN, Connelly PW, Hegele RA Paraoxonase: biochemistry, genetics and relationship to plasma lipoproteins. Curr Opin Lipidol 1996, 7:69-76.

5. Aviram M, Rosenblat M: Paraoxonases 1, 2, and 3, oxidative stress, and macrophage foam cell formation during atherosclerosis development. Free Radic Biol Med 2004, 37:1304-1316.

6. Loscalzo J: Paraoxonase and coronary heart disease risk: language misleads, linkage misinforms, function clarifies. Circ Cardiovasc Genet 2008, 1:79-80.

7. Draganov DI, Teiber JF, Speelman A, Osawa Y, Sunahara R, La Du BN: Human paraoxonases (PON1, PON2, and PON3) are lactonases with overlapping and distinct substrate specificities. J Lipid Res 2005, 46:1239-1247

8. Jakubowski $\mathrm{H}$ : Calcium-dependent human serum homocysteine thiolactone hydrolase. A protective mechanism against protein Nhomocysteinylation. J Biol Chem 2000, 275:3957-3962.

9. Clarke R, Lewington S, Sherliker P, Armitage J: Effects of B-vitamins on plasma homocysteine concentrations and on risk of cardiovascular disease and dementia. Curr Opin Clin Nutr Metab Care 2007, 10:32-39.

10. Jakubowski $\mathrm{H}$ : The role of paraoxonase 1 in the detoxification of homocysteine thiolactone. Adv Exp Med Biol 2010, 660:113-127.

11. Fuhrman B, Volkova N, Aviram M: Paraoxonase 1 (PON1) is present in postprandial chylomicrons. Atherosclerosis 2005, 180:55-61.

12. Watson AD, Berliner JA, Hama SY, La Du BN, Faull KF, Fogelman AM, Navab $M$ : Protective effect of high density lipoprotein associated paraoxonase. Inhibition of the biological activity of minimally oxidized low density lipoprotein. J Clin Invest 1995, 96:2882-2891.

13. Mackness B, Hine D, Liu Y, Mastorikou M, Mackness M: Paraoxonase-1 inhibits oxidised LDL-induced MCP-1 production by endothelial cells. Biochem Biophys Res Commun 2004, 318:680-683.

14. Steinberg D, Carew TE, Fielding C, Fogelman AM, Mahley RW, Sniderman $A D$, Zilversmit DB: Lipoproteins and the pathogenesis of atherosclerosis. Circulation 1989, 80:719-723.

15. Aviram M: Modified forms of low density lipoprotein and atherosclerosis. Atherosclerosis 1993, 98:1-9.

16. Witztum $J$, Steinberg D: Role of oxidized low density lipoprotein in atherogenesis. J Clin Invest 1991, 88:1785-1792.
17. Rosenblat M, Vaya J, Shih D, Aviram M: Paraoxonase 1 (PON1) enhances HDL-mediated macrophage cholesterol efflux via the ABCA1 transporter in association with increased HDL binding to the cells: a possible role for lysophosphatidylcholine. Atherosclerosis 2005, 179:69-77.

18. Rozenberg O, Rosenblat M, Coleman R, Shih DM, Aviram M: Paraoxonase (PON1) deficiency is associated with increased macrophage oxidative stress: studies in PON1-knockout mice. Free Radic Biol Med 2003, 34:774-784

19. Mackness Ml, Durrington PN, Ayub A, Mackness B: Low serum paraoxonase: a risk factor for atherosclerotic disease? Chem Biol Interact 1999, 119-120:389-397.

20. Mackness MI, Arrol S, Durrington PN: Paraoxonase prevents accumulation of lipoperoxides in low-density lipoprotein. FEBS Lett 1991, 286:152-154.

21. Deakin SP, Bioletto S, Bochaton-Piallat ML, James RW: HDL-associated paraoxonase-1 can redistribute to cell membranes and influence sensitivity to oxidative stress. Free Radic Biol Med 2011, 50:102-109.

22. Shih DM, Gu L, Xia YR, Navab M, Li WF, Hama S, Castellani LW, Furlong CE, Costa LG, Fogelman AM, Lusis AJ: Mice lacking serum paraoxonase are susceptible to organophosphate toxicity and atherosclerosis. Nature 1998, 394:284-287

23. Shih DM, Xia YR, Wang XP, Miller E, Castellani LW, Subbanagounder G, Cheroutre H, Faull KF, Berliner JA, Witztum JL, Lusis AJ: Combined serum paraoxonase knockout/apolipoprotein E knockout mice exhibit increased lipoprotein oxidation and atherosclerosis. J Biol Chem 2000, 275:17527-17535.

24. Berrougui $H$, Loued S, Khalil A: Purified human paraoxonase-1 interacts with plasma membrane lipid rafts and mediates cholesterol efflux from macrophages. Free Radic Biol Med 2012.

25. Ng DS, Chu T, Esposito B, Hui P, Connelly PW, Gross PL: Paraoxonase-1 deficiency in mice predisposes to vascular inflammation, oxidative stress, and thrombogenicity in the absence of hyperlipidemia. Cardiovasc Pathol 2008, 17:226-232.

26. Fuhrman B, Gantman A, Aviram M: Paraoxonase 1 (PON1) deficiency in mice is associated with reduced expression of macrophage SR-BI and consequently the loss of HDL cytoprotection against apoptosis. Atherosclerosis 2010, 211:61-68.

27. Rosenblat M, Volkova N, Ward J, Aviram M: Paraoxonase 1 (PON1) inhibits monocyte-to-macrophage differentiation. Atherosclerosis 2011, 219:49-56.

28. Coombes RH, Crow JA, Dail MB, Chambers HW, Wills RW, Bertolet BD, Chambers JE: Relationship of human paraoxonase-1 serum activity and genotype with atherosclerosis in individuals from the Deep South. Pharmacogenet Genomics 2011, 21:867-875.

29. Ng CJ, Wadleigh DJ, Gangopadhyay A, Hama S, Grijalva VR, Navab M, Fogelman AM, Reddy ST: Paraoxonase- 2 is a ubiquitously expressed protein with antioxidant properties and is capable of preventing cellmediated oxidative modification of low density lipoprotein. J Biol Chem 2001, 276:44444-44449.

30. Rosenblat M, Draganov D, Watson CE, Bisgaier CL, La Du BN, Aviram M: Mouse macrophage paraoxonase 2 activity is increased whereas cellular paraoxonase 3 activity is decreased under oxidative stress. Arterioscler Thromb Vasc Biol 2003, 23:468-474.

31. Ng CJ, Hama SY, Bourquard N, Navab M, Reddy ST: Adenovirus mediated expression of human paraoxonase 2 protects against the development of atherosclerosis in apolipoprotein E-deficient mice. Mol Genet Metab 2006, 89:368-373.

32. Ng CJ, Bourquard N, Grijalva V, Hama S, Shih DM, Navab M, Fogelman AM, Lusis AJ, Young S, Reddy ST: Paraoxonase-2 deficiency aggravates atherosclerosis in mice despite lower apolipoprotein-B-containing lipoproteins: anti-atherogenic role for paraoxonase-2. J Biol Chem 2006, 281:29491-29500.

33. Meilin E, Aviram M, Hayek T: Paraoxonase 2 (PON2) decreases high glucose-induced macrophage triglycerides (TG) accumulation, via inhibition of NADPH-oxidase and DGAT1 activity: studies in PON2deficient mice. Atherosclerosis 2010, 208:390-395.

34. Rosenblat M, Coleman R, Reddy ST, Aviram M: Paraoxonase 2 attenuates macrophage triglyceride accumulation via inhibition of diacylglycerol acyltransferase 1. J Lipid Res 2009, 50:870-879.

35. Shamir R, Hartman C, Karry R, Pavlotzky E, Eliakim R, Lachter J, Suissa A, Aviram M: Paraoxonases (PONs) 1, 2, and 3 are expressed in human and mouse gastrointestinal tract and in Caco-2 cell line: selective secretion of PON1 and PON2. Free Radic Biol Med 2005, 39.336-344. 
36. Levy E, Trudel K, Bendayan M, Seidman E, Delvin E, Elchebly M, Lavoie JC, Precourt LP, Amre D, Sinnett D: Biological role, protein expression, subcellular localization, and oxidative stress response of paraoxonase 2 in the intestine of humans and rats. Am J Physiol Gastrointest Liver Physiol 2007, 293:G1252-G1261.

37. Draganov DI, Stetson PL, Watson CE, Billecke SS, La Du BN: Rabbit serum paraoxonase 3 (PON3) is a high density lipoprotein-associated lactonase and protects low density lipoprotein against oxidation. J Biol Chem 2000, 275:33435-33442.

38. Reddy ST, Devarajan A, Bourquard N, Shih D, Fogelman AM: Is it just paraoxonase 1 or are other members of the paraoxonase gene family implicated in atherosclerosis? Curr Opin Lipidol 2008, 19:405-408.

39. Shih DM, Xia YR, Yu JM, Lusis AJ: Temporal and tissue-specific patterns of Pon3 expression in mouse: in situ hybridization analysis. Adv Exp Med Biol 2010, 660:73-87.

40. Reddy ST, Wadleigh DJ, Grijalva V, Ng C, Hama S, Gangopadhyay A, Shih DM, Lusis AJ, Navab M, Fogelman AM: Human paraoxonase-3 is an HDLassociated enzyme with biological activity similar to paraoxonase-1 protein but is not regulated by oxidized lipids. Arterioscler Thromb Vasc Biol 2001, 21:542-547.

41. Ng CJ, Bourquard N, Hama SY, Shih D, Grijalva VR, Navab M, Fogelman AM Reddy ST: Adenovirus-mediated expression of human paraoxonase 3 protects against the progression of atherosclerosis in apolipoprotein Edeficient mice. Arterioscler Thromb Vasc Biol 2007, 27:1368-1374.

42. Shih DM, Xia YR, Wang XP, Wang SS, Bourquard N, Fogelman AM, Lusis AJ, Reddy ST: Decreased obesity and atherosclerosis in human paraoxonase 3 transgenic mice. Circ Res 2007, 100:1200-1207.

43. Singh PK, Parsek MR, Greenberg EP, Welsh MJ: A component of innate immunity prevents bacterial biofilm development. Nature 2002, 417:552-555.

44. Miller MB, Bassler BL: Quorum sensing in bacteria. Annu Rev Microbiol 2001, 55:165-199.

45. Ross R: The pathogenesis of atherosclerosis: a perspective for the 1990s. Nature 1993, 362:801-809.

46. Epstein SE, Zhou YF, Zhu J: Infection and atherosclerosis: emerging mechanistic paradigms. Circulation 1999, 100:e20-e28.

47. Stocker R, Keaney JF Jr: Role of oxidative modifications in atherosclerosis. Physiol Rev 2004, 84:1381-1478.

48. Rosenfeld ME, Campbell LA: Pathogens and atherosclerosis: Update on the potential contribution of multiple infectious organisms to the pathogenesis of atherosclerosis. Thromb Haemost 2011, 106:858-867.

49. Libby P, Ridker PM, Maseri A: Inflammation and atherosclerosis. Circulation 2002, 105:1135-1143.

50. Han CY, Chiba T, Campbell JS, Fausto N, Chaisson M, Orasanu G, Plutzky J, Chait $A$ : Reciprocal and coordinate regulation of serum amyloid $A$ versus apolipoprotein $\mathrm{A}-\mathrm{I}$ and paraoxonase-1 by inflammation in murine hepatocytes. Arterioscler Thromb Vasc Biol 2006, 26:1806-1813.

51. Bin Ali A, Zhang Q, Lim YK, Fang D, Retnam L, Lim SK: Expression of major $\mathrm{HDL}$-associated antioxidant PON-1 is gender dependent and regulated during inflammation. Free Radic Biol Med 2003, 34:824-829.

52. Kumon $Y$, Suehiro T, Ikeda Y, Hashimoto K: Human paraoxonase-1 gene expression by HepG2 cells is downregulated by interleukin-1beta and tumor necrosis factor-alpha, but is upregulated by interleukin-6. Life SC 2003, 73:2807-2815.

53. Draganov D, Teiber J, Watson C, Bisgaier C, Nemzek J, Remick D, Standiford T, La Du B: PON1 and oxidative stress in human sepsis and an animal model of sepsis. Adv Exp Med Biol 2010, 660:89-97.

54. Novak F, Vavrova L, Kodydkova J, Novak F Sr: Hynkova M, Zak A, Novakova O: Decreased paraoxonase activity in critically ill patients with sepsis. Clin Exp Med 2010, 10:21-25.

55. Naderi M, Hashemi M, Komijani-Bozchaloei F, Moazeni-Roodi A, Momenimoghaddam M: Serum paraoxonase and arylesterase activities in patients with pulmonary tuberculosis. Pathophysiology 2011, 18:117-120.

56. Nezami N, Ghorbanihaghjo A, Rashtchizadeh N, Argani H, Tafrishinejad A, Ghorashi S, Hajhosseini B: Atherogenic changes of low-density lipoprotein susceptibility to oxidation, and antioxidant enzymes in pulmonary tuberculosis. Atherosclerosis 2011, 217:268-273.

57. Aslan M, Nazligul Y, Horoz M, Bolukbas C, Bolukbas FF, Gur M, Celik H, Erel O: Serum paraoxonase-1 activity in Helicobacter pylori infected subjects Atherosclerosis 2008, 196:270-274.
58. Kuo CC, Jackson LA, Campbell LA, Grayston JT: Chlamydia pneumoniae (TWAR). Clin Microbiol Rev 1995, 8:451-461.

59. Campbell LA, Kuo CC: Chlamydia pneumoniae-an infectious risk factor for atherosclerosis? Nat Rev Microbiol 2004, 2:23-32.

60. Campbell LA, Yaraei K, Van Lenten B, Chait A, Blessing E, Kuo CC, Nosaka T, Ricks J, Rosenfeld ME: The acute phase reactant response to respiratory infection with Chlamydia pneumoniae: implications for the pathogenesis of atherosclerosis. Microbes Infect 2010, 12:598-606.

61. Ozer EA, Pezzulo A, Shih DM, Chun C, Furlong C, Lusis AJ, Greenberg EP, Zabner J: Human and murine paraoxonase 1 are host modulators of Pseudomonas aeruginosa quorum-sensing. FEMS Microbiol Lett 2005, 253:29-37.

62. Khersonsky O, Tawfik DS: Structure-reactivity studies of serum paraoxonase PON1 suggest that its native activity is lactonase. Biochemistry (Mosc) 2005, 44:6371-6382.

63. Camps J, Pujol I, Ballester F, Joven J, Simo JM: Paraoxonases as potential antibiofilm agents: their relationship with quorum-sensing signals in Gram-negative bacteria. Antimicrob Agents Chemother 2011, 55:1325-1331.

64. Turkay C, Saba R, Sahin N, Altunbas H, Ozbudak O, Akkaya B, Ozbilim G, Colbasi I, Turkay M, Ogunc D, Bayezid O: Effect of chronic Pseudomonas aeruginosa infection on the development of atherosclerosis in a rat model. Clin Microbiol Infect 2004, 10:705-708.

65. Hu H, Pierce GN, Zhong G: The atherogenic effects of chlamydia are dependent on serum cholesterol and specific to Chlamydia pneumoniae. J Clin Invest 1999, 103:747-753.

66. Chun CK, Ozer EA, Welsh MJ, Zabner J, Greenberg EP: Inactivation of a Pseudomonas aeruginosa quorum-sensing signal by human airway epithelia. Proc Natl Acad Sci U S A 2004, 101:3587-3590.

67. Stoltz DA, Ozer EA, Ng CJ, Yu JM, Reddy ST, Lusis AJ, Bourquard N, Parsek MR, Zabner J, Shih DM: Paraoxonase-2 deficiency enhances Pseudomonas aeruginosa quorum sensing in murine tracheal epithelia. Am J Physiol Lung Cell Mol Physiol 2007, 292:L852-L860.

68. Kim JB, Xia YR, Romanoski CE, Lee S, Meng Y, Shi YS, Bourquard N, Gong KW, Port Z, Grijalva V, Reddy ST, Berliner JA, Lusis AJ, Shih DM: Paraoxonase- 2 modulates stress response of endothelial cells to oxidized phospholipids and a bacterial quorum-sensing molecule. Arterioscler Thromb Vasc Biol 2011, 31:2624-2633.

69. Horke S, Witte I, Wilgenbus P, Altenhofer S, Kruger M, Li H, Forstermann U: Protective effect of paraoxonase- 2 against endoplasmic reticulum stressinduced apoptosis is lost upon disturbance of calcium homoeostasis. Biochem J 2008, 416:395-405.

70. Horke S, Witte I, Altenhofer S, Wilgenbus P, Goldeck M, Forstermann U, Xiao J, Kramer GL, Haines DC, Chowdhary PK, Haley RW, Teiber JF: Paraoxonase 2 is down-regulated by the Pseudomonas aeruginosa quorumsensing signal N-(3-oxododecanoyl)-L-homoserine lactone and attenuates oxidative stress induced by pyocyanin. Biochem J 2010, 426:73-83.

71. Marsillach J, Mackness B, Mackness M, Riu F, Beltran R, Joven J, Camps J: Immunohistochemical analysis of paraoxonases-1, 2, and 3 expression in normal mouse tissues. Free Radic Biol Med 2008, 45:146-157.

72. Minick CR, Fabricant CG, Fabricant J, Litrenta MM: Atheroarteriosclerosis induced by infection with a herpesvirus. Am J Pathol 1979, 96:673-706.

73. Hauer AD, de Vos P, Peterse N, ten Cate H, van Berkel TJ, Stassen FR, Kuiper $\mathrm{J}$ : Delivery of Chlamydia pneumoniae to the vessel wall aggravates atherosclerosis in LDLr-/- mice. Cardiovasc Res 2006, 69:280-288.

74. Ezzahiri R, Nelissen-Vrancken HJ, Kurvers HA, Stassen FR, Vliegen I, Grauls GE, van Pul MM, Kitslaar PJ, Bruggeman CA: Chlamydophila pneumoniae (Chlamydia pneumoniae) accelerates the formation of complex atherosclerotic lesions in Apo E3-Leiden mice. Cardiovasc Res 2002, 56:269-276

75. Feingold KR, Memon RA, Moser AH, Grunfeld C: Paraoxonase activity in the serum and hepatic mRNA levels decrease during the acute phase response. Atherosclerosis 1998, 139:307-315.

76. Van Lenten BJ, Wagner AC, Nayak DP, Hama S, Navab M, Fogelman AM: High-density lipoprotein loses its anti-inflammatory properties during acute influenza a infection. Circulation 2001, 103:2283-2288.

77. Ali EM, Shehata HH, Ali-Labib R: Esmail Zahra LM: Oxidant and antioxidant of arylesterase and paraoxonase as biomarkers in patients with hepatitis $C$ virus. Clin Biochem 2009, 42:1394-1400.

78. García-Heredia A, Marsillach J, Aragonès G, Guardiola M, Rull A, BeltranDèbón R, Folch A, Mackness B, Mackness M, Pedro-Botet J, Joven J, Camps $\mathrm{J}$ : Serum paraoxonase-3 concentration is associated with the severity of 
hepatic impairment in patients with chronic liver disease. Clin Biochem 2011, 44:1320-1324

79. Schulpis KH, Barzeliotou A, Papadakis M, Rodolakis A, Antsaklis A, Papassotiriou I, Vlachos GD: Maternal chronic hepatitis B virus is implicated with low neonatal paraoxonase/arylesterase activities. Clin Biochem 2008, 41:282-287.

80. Duygu F: Tekin Koruk S, Aksoy N: Serum paraoxonase and arylesterase activities in various forms of hepatitis B virus infection. J Clin Lab Anal 2011, 25:311-316.

81. He QY, Lau GK, Zhou Y, Yuen ST, Lin MC, Kung HF, Chiu JF: Serum biomarkers of hepatitis $B$ virus infected liver inflammation: a proteomic study. Proteomics 2003, 3:666-674.

82. Fernández-Irigoyen J, Santamaría E, Sesma L, Muñoz J, Riezu Jl, Caballeria J, Lu SC, Prieto J, Mato JM, Avila MA, Corrales FJ: Oxidation of specific methionine and tryptophan residues of apolipoprotein A-I in hepatocarcinogenesis. Proteomics 2005, 5:4964-4972.

83. Rose H, Woolley I, Hoy J, Dart A, Bryant B, Mijch A, Sviridov D: HIV infection and high-density lipoprotein: the effect of the disease vs the effect of treatment. Metabolism 2006, 55:90-95.

84. Parra S, Alonso-Villaverde C, Coll B, Ferré N, Marsillach J, Aragonès G, Mackness M, Mackness B, Masana L, Joven J, Camps J: Serum paraoxonase1 activity and concentration are influenced by human immunodeficiency virus infection. Atherosclerosis 2007, 194:175-181.

85. Yuan J, Devarajan A, Moya-Castro R, Zhang M, Evans S, Bourquard N, Dias P, Lacout C, Vainchenker W, Reddy ST, Koka PS: Putative innate immunity of antiatherogenic paraoxanase-2 via STAT5 signal transduction in HIV-1 infection of hematopoietic TF-1 cells and in SCID-hu mice. J Stem Cells 2010, 5:43-48.

86. Aragonès $G$, García-Heredia A, Guardiola M, Rull A, Beltran-Dèbón R, Marsillach J, Alonso-Villaverde C, Mackness B, Mackness M, Pedro-Botet J, Pardo-Reche P, Joven J, Camps J: Serum paraoxonase-3 concentration in HIV-infected patients. Evidence for a protective role against oxidation. J Lipid Res 2012, 53:168-174.

87. Francisco AF: de Abreu Vieira PM, Arantes JM, Silva M, Pedrosa ML, Eloi-Santos SM, Martins-Filho OA, Teixeira-Carvalho A, Araújo MS, Tafuri WL, Carneiro CM: Increase of reactive oxygen species by desferrioxamine during experimental Chagas' disease. Redox Rep 2010, 15:185-190.

88. Sunnemark D, Ulfgren AK, Örn A, Harris RA: Cytokine production in hearts of Trypanosoma cruzi-infected CBA mice: Do cytokine patterns in chronic stage reflect the establishment of myocardial pathology? Scand J Immunol 1996, 44:421-429.

89. Manque PA, Probst CM, Pereira MC, Rampazzo RC, Ozaki LS, Pavoni DP: Silva Neto DT, Carvalho MR, Xu P, Serrano MG, Alves JM, Meirelles Mde N, Goldenberg S, Krieger MA, Buck GA: Trypanosoma cruzi infection induces a global host cell response in cardiomyocytes. Infect Immun 2011, 79:1855-1862.

90. Guedes PM, Veloso VM, Talvani A, Diniz LF, Caldas IS, Do-Valle-Matta MA Santiago-Silva J, Chiari E, Galvao LM, Silva JS, Bahia MT: Increased type 1 chemokine expression in experimental Chagas disease correlates with cardiac pathology in beagle dogs. Vet Immunol Immunopathol 2010 138:106-113.

91. Vitelli-Avelar DM, Sathler-Avelar R, Massara RL, Borges JD, Lage PS, Lana M, Teixeira-Carvalho A, Dias JC, Eloi-Santos SM, Martins-Filho OA: Are increased frequency of macrophage-like and natural killer (NK) cells, together with high levels of NKT and CD4+CD25high T cells balancing activated CD8+ T cells, the key to control Chagas' disease morbidity? Clin Exp Immunol 2006, 145:81-92.

92. Farid AS, Nakahara K, Murakami N, Hayashi T, Horii Y: Decreased serum paraoxonase-1 activity during intestinal nematode (Nippostrongylus brasiliensis) infection in rats. Am J Trop Med Hyg 2008, 78:770-776.

93. Farid AS, Shimohira T, Kobayashi I, Sawada J, Horii Y: Intestinally implanted Nippostrongylus brasiliensis adult worms decrease serum paraoxonase-1 activity in rats. Parasitol Int 2009, 58:178-183.

94. Farid AS, Mido S, Linh BK, Hayashi T, Horii Y: An atherogenic lipid profile with low serum paraoxonase-1 activity during nematode infection in rats. Eur J Clin Invest 2010, 40:984-993.

95. Mido S, Fath EM, Farid AS, Nonaka N, Oku Y, Horii Y: Trichinella spiralis: Infection changes serum paraoxonase-1 levels, lipid profile, and oxidative status in rats. Exp Parasitol 2012, 131:190-194.
96. Helmy MM, Mahmoud SS, Fahmy ZH: Schistosoma mansoni: effect of dietary zinc supplement on egg granuloma in Swiss mice treated with praziqantel. Exp Parasitol 2009, 122:310-317.

97. Choi J: Ou JH: Mechanisms of liver injury. III. Oxidative stress in the pathogenesis of hepatitis C virus. Am J Physiol Gastrointest Liver Physiol 2006 290:G847-G851.

98. Piccoli C, Scrima R, Quarato G, D'Aprile A, Ripoli M, Lecce L, Boffoli D, Moradpour D, Capitanio N: Hepatitis C virus protein expression causes calcium-mediated mitochondrial bioenergetic dysfunction and nitrooxidative stress. Hepatology 2007, 46:58-65.

99. Miura K, Taura K, Kodama Y, Schnabl B, Brenner DA: Hepatitis C virusinduced oxidative stress suppresses hepcidin expression through increased histone deacetylase activity. Hepatology 2008, 48:1420-1429.

100. Tang H, Grisè H: Cellular and molecular biology of HCV infection and hepatitis. Clin Sci (Lond) 2009, 117:49-65.

101. González-Gallego J, García-Mediavilla MV, Sánchez-Campos S: Hepatitis C virus, oxidative stress and steatosis: current status and perspectives. Curr Mol Med 2011, 11:373-390.

102. Ferré N, Camps J, Cabre M, Paul A, Joven J: Hepatic paraoxonase activity alterations and free radical production in rats with experimental cirrhosis. Metabolism 2001, 50:997-1000

103. Mackness B, Davies GK, Turkie W, Lee E, Roberts DH, Hill E, Roberts C, Durrington PN, Mackness Ml: Paraoxonase status in coronary heart disease: are activity and concentration more important than genotype? Arterioscler Thromb Vasc Biol 2001, 21:1451-1457.

104. Deakin SP, James RW: Genetic and environmental factors modulating serum concentrations and activities of the antioxidant enzyme paraoxonase-1. Clin Sci (Lond) 2004, 107:435-447.

105. Ferré N, Marsillach J, Camps J, Rull A, Coll B, Tous M, Joven J: Genetic association of paraoxonase-1 polymorphisms and chronic hepatitis $C$ virus infection. Clin Chim Acta 2005, 361:206-210.

106. Aviram M, Hardak E, Vaya J, Mahmood S, Milo S, Hoffman A, Billicke S, Draganov D, Rosenblat M: Human serum paraoxonases (PON1) Q and R selectively decrease lipid peroxides in human coronary and carotid atherosclerotic lesions: PON1 esterase and peroxidase-like activities. Circulation 2000, 101:2510-2517.

107. Kono Y, Hayashida K, Tanaka H, Ishibashi H, Harada M: High-density lipoprotein binding rate differs greatly between genotypes $1 \mathrm{~b}$ and $2 \mathrm{a} /$ 2b of hepatitis C virus. J Med Virol 2003, 70:42-48.

108. Mohamadkhani A, Sayemiri K, Ghanbari R, Elahi E, Poustchi H, Montazeri G: The inverse association of serum HBV DNA level with HDL and adiponectin in chronic hepatitis B infection. Virol J 2010, 7:228.

109. Currier JS, Lundgren JD, Carr A, Klein D, Sabin CA, Sax PE, Schouten JT, Smieja M: Epidemiological evidence for cardiovascular disease in HIVinfected patients and relationship to highly active antiretroviral therapy. Circulation 2008, 118:e29-e35.

110. Seigneur M, Constans J, Blann A, Renard M, Pellegrin JL, Amiral J, Boisseau $\mathrm{M}$, Conri $\mathrm{C}$ : Soluble adhesion molecules and endothelial cell damage in HIV infected patients. Thromb Haemost 1997, 77:646-649.

111. Dubè MP, Lipshultz SE, Fichtenbaum CJ, Greenberg R, Schecter AD, Fisher SD: Effects of HIV infection and antiretroviral therapy on the heart and vasculature. Circulation 2008, 118:e36-e40.

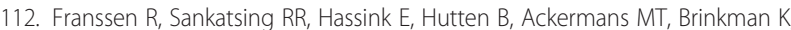
Oesterholt R, Arenas-Pinto A, Storfer SP, Kastelein JJ, Sauerwein HP, Reiss P, Stroes ES: Nevirapine increases high-density lipoprotein cholesterol concentration by stimulation of apolipoprotein A-I production. Arterioscler Thromb Vasc Biol 2009, 29:1336-1341.

113. Gaidukov L, Tawfik DS: High affinity, stability, and lactonase activity of serum paraoxonase PON1 anchored on HDL with ApoA-I. Biochemistry (Mosc) 2005, 44:11843-11854

114. Pereira SA, Batuca JR, Caixas U, Branco T, Delgado-Alves J, Germano I, Lampreia F, Monteiro EC: Effect of efavirenz on high-density lipoprotein antioxidant properties in HIV-infected patients. Br J Clin Pharmacol 2009, 68:891-897.

115. Aragonès $G$, Beltran-Dèbón R, Rull A, Rodríguez-Sanabria F, FernándezSender L, Camps J, Joven J, Alonso-Villaverde C: Human immunodeficiency virus-infection induces major changes in high-density lipoprotein particle size distribution and composition: the effect of antiretroviral treatment and disease severity. Clin Chem Lab Med 2010, 48:1147-1152.

116. Lo J, Abbara S, Shturman L, Soni A, Wei J, Rocha-Filho JA, Nasir K, Grinspoon SK: Increased prevalence of subclinical coronary atherosclerosis detected 
by coronary computed tomography angiography in HIV-infected men. AIDS 2010, 24:243-253.

117. Dowling DK, Simmons LW: Reactive oxygen species as universal constraints in life-history evolution. Proc Biol Sci 2009, 276:1737-1745.

118. van de Crommenacker J, Richardson DS, Koltz AM, Hutchings K, Komdeur $\mathrm{J}$ : Parasitic infection and oxidative status are associated and vary with breeding activity in the Seychelles warbler. Proc Biol Sci 2012, 279:1466-1476.

119. Steinberg D: The LDL modification hypothesis of atherogenesis: an update. J Lipid Res 2009, 50(Suppl):S376-S381.

120. Quinnell RJ, Bethony J, Pritchard DI: The immunoepidemiology of human hookworm infection. Parasite Immunol 2004, 26:443-454

121. Loukas A, Prociv P: Immune responses in hookworm infections. Clin Microbiol Rev 2001, 14:689-703. table of contents.

122. Beard CB, Pye G, Steurer FJ, Rodriguez R, Campman R, Peterson AT, Ramsey J, Wirtz RA, Robinson LE: Chagas disease in a domestic transmission cycle, southern Texas, USA. Emerg Infect Dis 2003, 9:103-105.

123. Rossi MA: Aortic endothelial cell changes in the acute septicemic phase of experimental Trypanosoma cruzi infection in rats: scanning and transmission electron microscopic study. Am J Trop Med Hyg 1997. 57:321-327.

124. Carvalho G, Rassi S, Bastos JM, Camara SS: Asymptomatic coronary artery disease in chagasic patients with heart failure: prevalence and risk factors. Arq Bras Cardiol 2011, 97:408-412.

125. Sunnemark D, Frostegard J, Örn A, Harris RA: Cellular and cytokine characterization of vascular inflammation in CBA/J mice chronically infected with Trypanosoma cruzi. Scand J Immunol 1998, 48:480-484

126. Ndao M, Spithill TW, Caffrey R, Li H, Podust VN, Perichon R, Santamaria C, Ache A, Duncan M, Powell MR, Ward BJ: Identification of novel diagnostic serum biomarkers for Chagas' disease in asymptomatic subjects by mass spectrometric profiling. J Clin Microbiol 2010, 48:1139-1149.

127. Atwood JA 3rd: Weatherly DB, Minning TA, Bundy B, Cavola C Opperdoes FR, Orlando R, Tarleton RL: The Trypanosoma cruzi proteome. science 2005, 309:473-476.

128. James RW, Deakin SP: The importance of high-density lipoproteins for paraoxonase-1 secretion, stability, and activity. Free Radic Biol Med 2004, 37:1986-1994

129. Raper J, Fung R, Ghiso J, Nussenzweig V, Tomlinson S: Characterization of a novel trypanosome lytic factor from human serum. Infect Immun 1999, 67:1910-1916.

130. Owen JS, Lorenz P, Betschart B: HDL particles as the trypanosome-killing factor in human serum: An exclusive or inconclusive role? Parasitol Today 1996, 12:250-251.

131. Bhasin KK, Yu JM, Tward A, Shih D, Campbell DA, Lusis AJ: Trypanosoma congolense: paraoxonase 1 prolongs survival of infected mice. Exp Parasitol 2006, 114:240-245.

132. Mackness B, Mackness M: Anti-inflammatory properties of paraoxonase-1 in atherosclerosis. Adv Exp Med Biol 2010, 660:143-151.

133. Harcus YM, Parkinson J, Fernández C, Daub J, Selkirk ME, Blaxter ML, Maizels RM: Signal sequence analysis of expressed sequence tags from the nematode Nippostrongylus brasiliensis and the evolution of secreted proteins in parasites. Genome Biol 2004, 5:R39.

134. Thomàs-Moyà E, Gianotti M, Proenza AM, Lladó I: Paraoxonase 1 response to a high-fat diet: gender differences in the factors involved. Mol Med 2007, 13:203-209.

135. Chiumiento L, Bruschi F: Enzymatic antioxidant systems in helminth parasites. Parasitol Res 2009, 105:593-603.

136. Aviram M, Rosenblat M, Billecke S, Erogul J, Sorenson R, Bisgaier CL, Newton RS, La Du B: Human serum paraoxonase (PON 1) is inactivated by oxidized low density lipoprotein and preserved by antioxidants. Free Radic Biol Med 1999, 26:892-904.

137. Chelur DS, Ernstrom GG, Goodman MB, Yao CA, Chen L: R OH, Chalfie M: The mechanosensory protein MEC- 6 is a subunit of the C. elegans touchcell degenerin channel. Nature 2002, 420:669-673.

138. Doenhoff MJ, Stanley RG, Griffiths K, Jackson CL: An anti-atherogenic effect of Schistosoma mansoni infections in mice associated with a parasite-induced lowering of blood total cholesterol. Parasitology 2002, 125:415-421.

139. Meyer F, Meyer H, Bueding E: Lipid metabolism in the parasitic and freeliving flatworms, Schistosoma mansoni and Dugesia dorotocephala. Biochim Biophys Acta 1970, 210:257-266.
140. Bennett MW, Caulfield JP: Specific binding of human low-density lipoprotein to the surface of schistosomula of Schistosoma mansoni and ingestion by the parasite. Am J Pathol 1991, 138:1173-1182.

141. Lima VL, Sena VL, Stewart B, Owen JS, Dolphin PJ: An evaluation of the marmoset Callithrix jacchus (sagüi) as an experimental model for the dyslipoproteinemia of human Schistosomiasis mansoni. Biochim Biophys Acta 1998, 1393:235-243.

142. Waknine-Grinberg JH, Gold D, Ohayon A, Flescher E, Heyfets A, Doenhoff MJ, Schramm G, Haas H, Golenser J: Schistosoma mansoni infection reduces the incidence of murine cerebral malaria. Malar J 2010, 9:5.

143. La Flamme AC, Harvie M, Kenwright D, Cameron K, Rawlence N, Low YS, McKenzie S: Chronic exposure to schistosome eggs reduces serum cholesterol but has no effect on atherosclerotic lesion development. Parasite Immunol 2007, 29:259-266.

144. Stanley RG, Jackson CL, Griffiths K, Doenhoff MJ: Effects of Schistosoma mansoni worms and eggs on circulating cholesterol and liver lipids in mice. Atherosclerosis 2009, 207:131-138.

145. Jawien J: New insights into immunological aspects of atherosclerosis. Pol Arch Med Wewn 2008, 118:127-131.

146. Laurat E, Poirier B, Tupin E, Caligiuri G, Hansson GK, Bariety J, Nicoletti A: In vivo downregulation of $\mathrm{T}$ helper cell 1 immune responses reduces atherogenesis in apolipoprotein E-knockout mice. Circulation 2001, 104:197-202.

147. de Boer OJ, van der Meer JJ, Teeling P, van der Loos CM, van der Wal AC: Low numbers of FOXP3 positive regulatory T cells are present in all developmental stages of human atherosclerotic lesions. PLoS One 2007, 2:e779.

148. Davenport P, Tipping PG: The role of interleukin-4 and interleukin-12 in the progression of atherosclerosis in apolipoprotein E-deficient mice. Am J Pathol 2003, 163:1117-1125.

doi:10.1186/1476-511X-11-92

Cite this article as: Farid and Horii: Modulation of paraoxonases during infectious diseases and its potential impact on atherosclerosis. Lipids in Health and Disease 2012 11:92.

\section{Submit your next manuscript to BioMed Central and take full advantage of:}

- Convenient online submission

- Thorough peer review

- No space constraints or color figure charges

- Immediate publication on acceptance

- Inclusion in PubMed, CAS, Scopus and Google Scholar

- Research which is freely available for redistribution 